\title{
SUB-FRAMES WITH REVERSE CHANNEL CONNECTIONS TO CFT COMPOSITE COLUMNS -EXPERIMENTAL EVALUATION
}

\author{
Fernanda Lopes ${ }^{1}$, Aldina Santiago ${ }^{1, *}$, Luís Simões da Silva ${ }^{1}$, Naveed Iqbal $^{2}$, \\ Milan Veljkovic ${ }^{2}$ and José Guilherme S. da Silva ${ }^{3}$ \\ ${ }^{1}$ ISISE - Department of Civil Engineering, University of Coimbra, Pólo II, 3030 Coimbra, Portugal \\ ${ }^{2}$ Division of Structural and Construction Engineering of the Luleå University of Technology, Luleå, Sweden \\ ${ }^{3}$ Department of Structural Engineering of the State University of Rio de Janeiro, Rio de Janeiro, Brazil \\ *(Corresponding author: E-mail: aldina@dec.uc.pt)
}

Received: 19 March 2014; Revised: 23 April 2014; Accepted: 5 May 2014

\begin{abstract}
This paper presents the experimental results of the investigation on the coupled joint-structure behaviour of the composite sub-frame, using the reverse channel connections between an I-beam and the concrete filled tube (CFT) columns. This experimental programme includes seven full-scale tests: three tests at ambient temperature and four tests under heating-cooling curves. The parametric study was dedicated to: temperature-time curve and channel wall thickness $(8,10$ and $12 \mathrm{~mm})$.

The main objective of these tests is to provide experimental information on the behaviour of the reverse channel joints and its influence on the structure under a heating-cooling fire. The restraining effects from the unaffected part of surrounding structure induce highly variable loading histories on the joints during fire; therefore the investigation on coupled joint-structure behaviour should lead to a realistic prediction of progressive collapse of the structure.
\end{abstract}

Keywords: Full-scale tests, Heating-cooling curves, Reverse channel connection, Concrete filled tubes, Robustness.

\section{INTRODUCTION}

Fire safety requirements have caused a significant cost increase of steel construction by implying a systematic need for fire protection, resulting from severe traditional prescriptive regulations [1], which can impose an extra $20 \%$ to $30 \%$ onto the cost of the steelwork [2]. Over the past few years, one of the main achievements of structural steel research has been the development of the new engineering methods of analysis and design that take into account the real conditions of fire and the real fire resistance of steel structures ([3], [4], [5]). Such methods allow safer and more economical design and construction of steel structures.

Composite structures are widely used to optimize fire resistance. Concrete-filled hollow sections combine the advantages of steel and concrete and they are often assumed to possess inherently high fire resistance without the use of steel rebars and provide continuous confinement of concrete. In addition, the use of concrete-filled hollow sections also improves the productivity by eliminating the need for formwork. However, connecting to hollow sections is complicated and expensive because there is no access to the inside of the sections. The most common arrangements for beam-to-column joints make use of bolted connections by means of attachments welded to the walls of the steel profile of the composite column; a typical example is the fin plate connection, using a flat plate welded to the column wall. An alternative joint configuration is the web cleat connection, using single- or double-angle sections, or T-sections, welded to the column wall. Additionally, the reverse channel connection has gradually become an alternative option for bolted connections to hollow sections.

Several experimental and analytical studies have been performed to characterize the moment-rotation behaviour of joints between concrete filled tubular columns and I-beams ([6], [7]) at ambient temperature. However, there is a paucity of knowledge on their behaviour in fire. 
The demand for connection performance to prevent fracture is very high in fire design for structural robustness, and a way to prevent fracture is to enhance the connection's ductility rather than its strength. The use of connections that deform and accommodate the large axial deformations that arise from thermally induced changes in beam length reduces the internal forces that are developed if these changes are resisted.

Different types of connections between concrete filled tubular columns and steel beams have been studied in fire to improve structural fire resistance enhancing of the deformational capacity of the joints to develop catenary action in the connected beam at high temperatures. In previous experimental studies on structural fire behaviour of different type of steel beam to concrete filled tubular column assemblies [8], the reverse channel connection appears to have the best combination of desirable features: moderate construction cost, ability to develop catenary action and extremely high ductility through deformation of the web channel. In a series of component and joint tests conducted during the European RFCS COMPFIRE project ([9], [10], [11]), the results showed that the reverse channel improved the rotational capacity of the connection and had an ultimate strength similar to an endplate connection tested at the same temperature. Within the same project, the effect of the surrounding structure was also evaluated and small-scale sub-frame tests under a standard fire curve ISO 834 were performed. It was observed that the reverse channel cut form hot-rolled tubes can give considerable deformation capacity to the connection, to enable the structure to survive to higher temperatures than the beam's conventional limiting temperature ([9], [12]).

The experimental tests presented in this paper investigated the behaviour of the reverse channel connections between a steel beam and two composite columns, during the entire fire and considering the development of bending, compression, local yielding and buckling and catenary action within the joint and its components.

\section{EXPERIMENTAL TESTS}

\subsection{Sub-frame and Testing Arrangement}

The experimental tests were performed at the Department of Civil Engineering of the University of Coimbra. Seven full-scale tests were performed: three tests at ambient temperature and four tests under two different heating curves, including cooling phase, as presented in Table 1.

Table 1. Experimental Programme

\begin{tabular}{|c|c|c|c|}
\hline Test $n^{\circ}$ & Temperature & Column section & Reverse channel connection \\
\hline 1 & Ambient & CHS $244.5 \times 10$ & C1 - U 200x135x8 \\
\hline 2 & Ambient & SHS 250x10 & S1 - U 200x90x8 \\
\hline 3 & Ambient & SHS $250 \times 10$ & $\mathrm{~S} 2-\mathrm{U} 200 \times 90 \times 10$ \\
\hline 4 & Heating $1+$ cooling & SHS $250 \times 10$ & $\mathrm{~S} 2-\mathrm{U} 200 \times 90 \times 10$ \\
\hline 5 & Heating $2+$ cooling & SHS $250 \times 10$ & S2 - U 200x90x10 \\
\hline 6 & Heating $1+$ cooling & SHS $250 \times 10$ & S1 - U 200x90x8 \\
\hline 7 & Heating $1+$ cooling & SHS $250 \times 10$ & S3 - U 200x90x12 \\
\hline
\end{tabular}

The basic configuration of the test sub-frames consisted of an I-beam IPE300 and two concrete filled tube columns (square or circular hollow sections). The beam was connected to the columns using reverse channel connections. The columns were $3525 \mathrm{~mm}$ tall and the beam span was $5000 \mathrm{~mm}$ (Figure 1). The beam was restrained against lateral movements at three points: at the beam mid-span and at $1000 \mathrm{~mm}$ on both side of the beam mid-span. The top and bottom restraints of the columns prevented horizontal movements at these points, but allowed the expansion of the columns at the top. 
The columns and beam, as well as the reverse channel section were of steel grade S355. The steel grade of endplate at the ends of the beam was S275. Concrete filling of the hollow section columns were grade C30/37 (more details are presented in Section \$2.4).

(a)

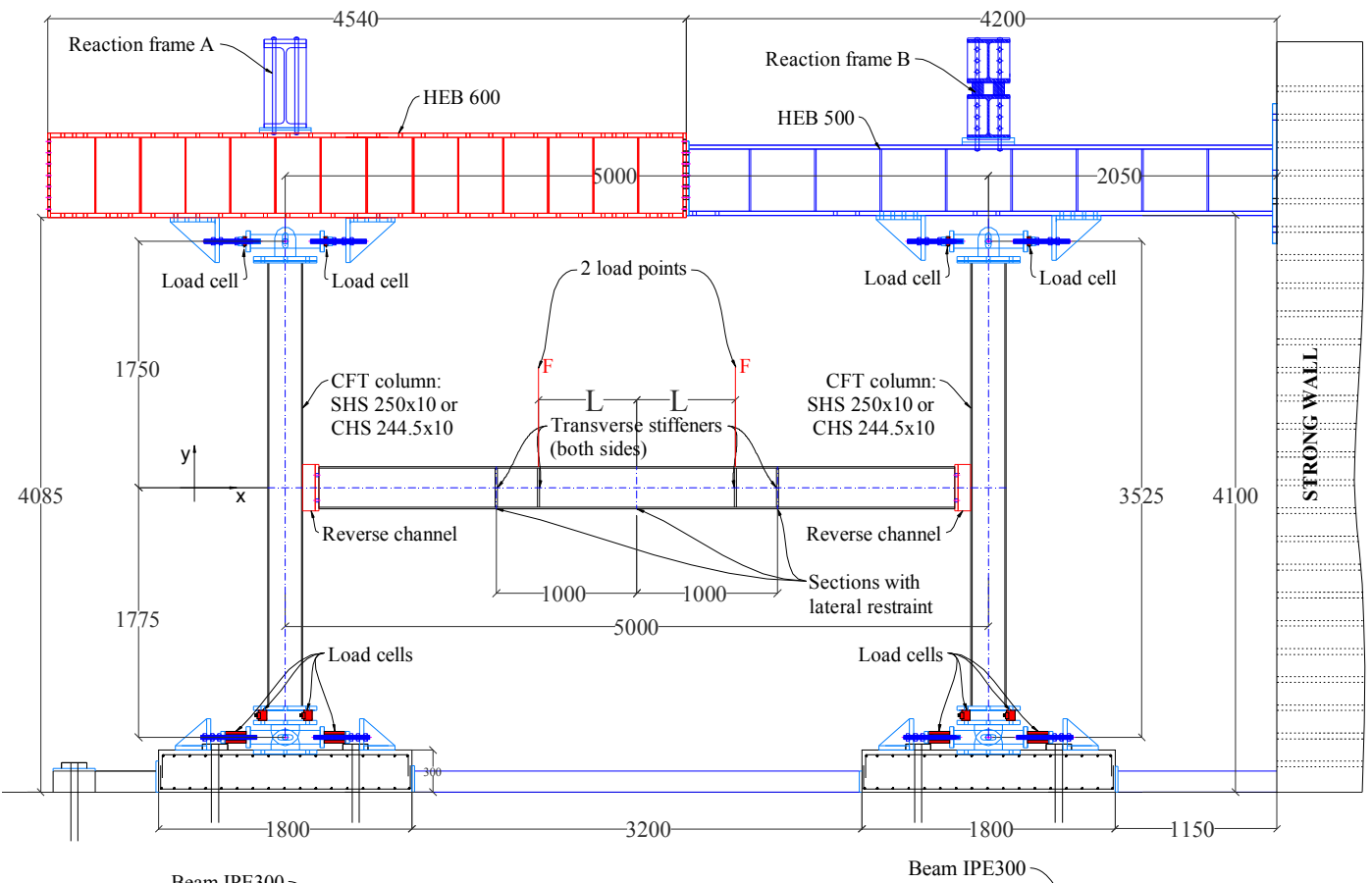

(b)

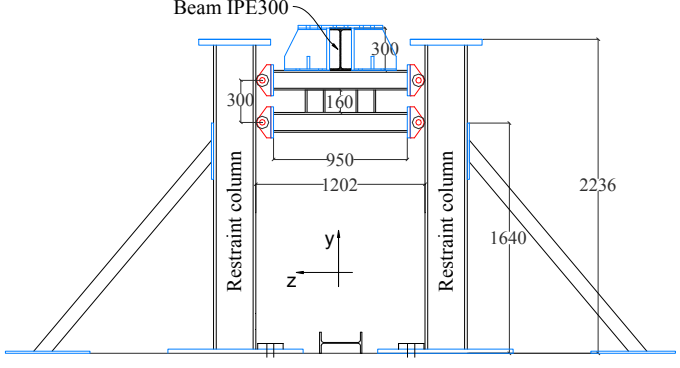

(c)

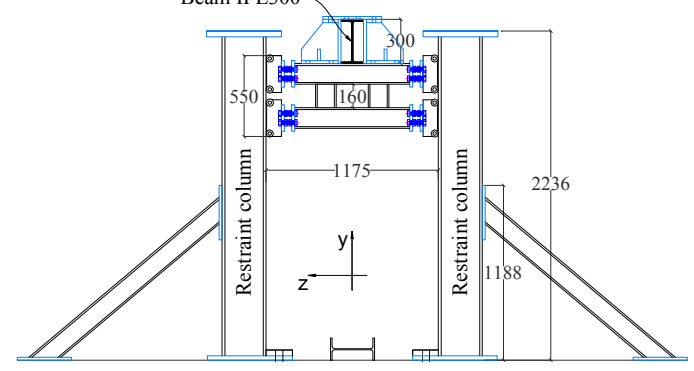

Figure 1. Outline of the Experimental Tests: (a) Elevation View; (b) Lateral Restraint at the Beam Mid-span; (c) Lateral Restraint at the Left and Right Sides of the Beam Mid-span

The reverse channel connections were built through a bolted endplate to web of a channel section with its flanges welded to the column face. Figure 2 illustrates the reverse channel connections to SHS and CHS columns. The bolts (M24) and the nuts were black grade 10.9. The reverse channel sections were fabricated from square hollow sections that were cut lengthwise. To reach these geometric dimensions, three different wall thicknesses of SHS200x200 were used: 8, 10 and $12 \mathrm{~mm}$.

The connections in the tests should presented high ductility to accommodate the large deflection of the beam. The connections were designed at ambient temperature according to the component method defined in EN 1993-1-8 [13] and in CIDECT Report 5BP-4/05 [14]. A detailed description of the design method and the identified components of the reverse channel joints have been found in [10]. The deformation of the loaded face of the reverse channel determined the resistance of the tested connections and the weakest component was the reverse channel in bending, except for those with wall thickness equal to $12 \mathrm{~mm}$, which presented the beam web in tension as the weakest component. Material properties from uniaxial tensile tests (section $\S 2.4$ ) were used in the 
analytical calculation without safety factor. The design moment resistance $\left(M_{j, R d}\right)$ of the joints $\mathrm{S} 1$ and $\mathrm{C} 1$ was 0.17 times the design plastic moment resistance of a beam $\left(M_{b, p l, R d}\right)$. They were classified as nominally pinned at ambient temperature. The joints S2 and S3 presented the design moment resistance greater than 0.25 times the design plastic moment resistance of the beam. They were classified as partial-strength. Regarding the initial stiffness $\left(S_{j, i n i}\right)$, all connections were semi-rigid (Table 2).

(a)

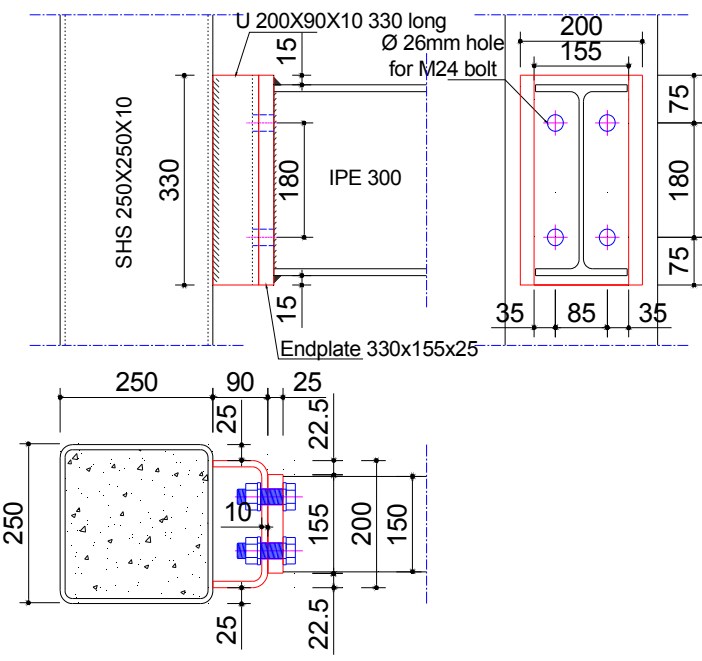

(b)

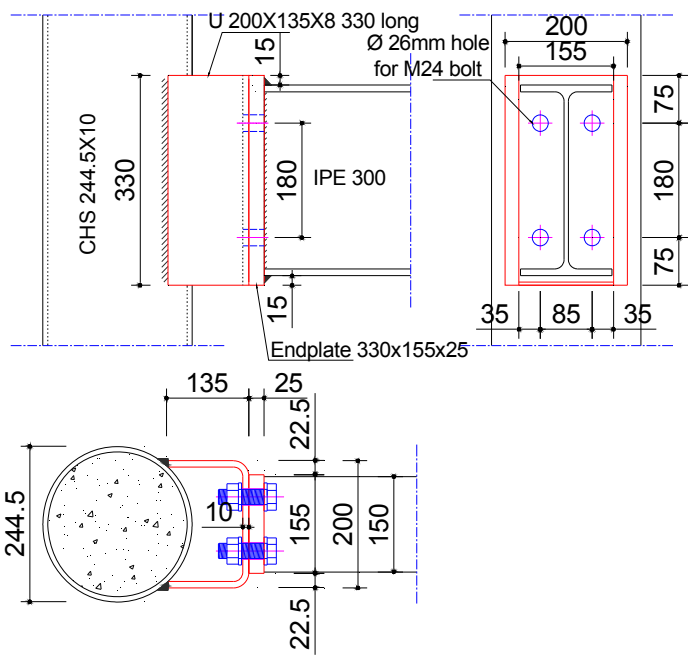

Figure 2. Reverse Channel Joints: (a) Square Column SHS 250x10 and Reverse Channel Connection S2; (b) Circular Column CHS 244.5x10 and Reverse Channel Connection C1

Table 2. Analytical Results of Stiffness and Strength of the Reverse Channel Connections

\begin{tabular}{|c|cc|ccc|}
\hline \multirow{2}{*}{$\begin{array}{c}\text { Reverse channel } \\
\text { connection }\end{array}$} & \multicolumn{2}{|c|}{ Stiffness } & \multicolumn{3}{c|}{ Strength } \\
\cline { 2 - 6 } & $\begin{array}{c}S_{j, \text { jini }}{ }^{*} \\
(\mathrm{kNm} / \mathrm{rad})\end{array}$ & Class. & $\begin{array}{c}M_{j, R d} \\
(\mathrm{kNm})\end{array}$ & $M_{j, R d} / b, p l, R d$ & Class. \\
\hline $\mathrm{S} 1 / \mathrm{C} 1\left(\mathrm{t}_{\mathrm{w}}=8 \mathrm{~mm}\right)$ & 8560.12 & Semi-rigid & 37.96 & 0.17 & Nominally pinned \\
$\mathrm{S} 2\left(\mathrm{t}_{\mathrm{w}}=10 \mathrm{~mm}\right)$ & 12970.40 & Semi-rigid & 94.62 & 0.42 & Partial-strength \\
$\mathrm{S} 3\left(\mathrm{t}_{\mathrm{w}}=12 \mathrm{~mm}\right)$ & 19699.26 & Semi-rigid & 101.98 & 0.46 & Partial-strength \\
\hline
\end{tabular}

\subsection{Mechanical and Thermal Loadings}

During the ambient temperature tests (Tests 1 to 3 ), the mechanical loading was continually increased by a hydraulic actuator (maximum test load $1000 \mathrm{kN}$, maximum piston stroke $\pm 150 \mathrm{~mm}$ ) at two points symmetrically located at $800 \mathrm{~mm}$ to either side of the beam mid-span. A reinforced HEB240, S355, was connected under the actuator to apply the load-increasing test with the aid of two cylinders $(\varnothing 80 \mathrm{~mm})$, as illustrated in Figure 3(a). The load was gradually applied under displacement control with a speed of $0.02 \mathrm{~mm} / \mathrm{s}$ until failure.

For all heating-cooling tests (Tests 4 to 7 ), two pairs of reinforced concrete blocks (700 $\mathrm{mm} \times 700$ $\mathrm{mm} \times 900 \mathrm{~mm}$ ) were used to apply the constant mechanical loading. Each pair of concrete blocks was positioned at ambient temperature hanging from a HEA100, transversely positioned and welded to the beam top flange (Figure 3(b)). Due to geometric limitations in the experimental layout, especially due to the dimensions of the concrete blocks and the positions of the lateral restraints, load points at $800 \mathrm{~mm}$ from the mid-span were no longer possible; so, they were symmetrically located $600 \mathrm{~mm}$ away from the beam mid-span. Two pairs of concrete blocks, two beams HEA100 and the lateral restraint devices contributed to the total amount of the applied load: $47 \mathrm{kN}$. The nominal load ratio was 0.20 , which is defined as the ratio of the applied load during the 
heating-cooling tests $\left(M_{\mathrm{fi}, \mathrm{Ed}}=45 \mathrm{kNm}\right)$ to the nominal loading-carrying capacity of the simply-supported beam at ambient temperature $\left(M_{\mathrm{Rd}}=223 \mathrm{kNm}\right)$.

(a)

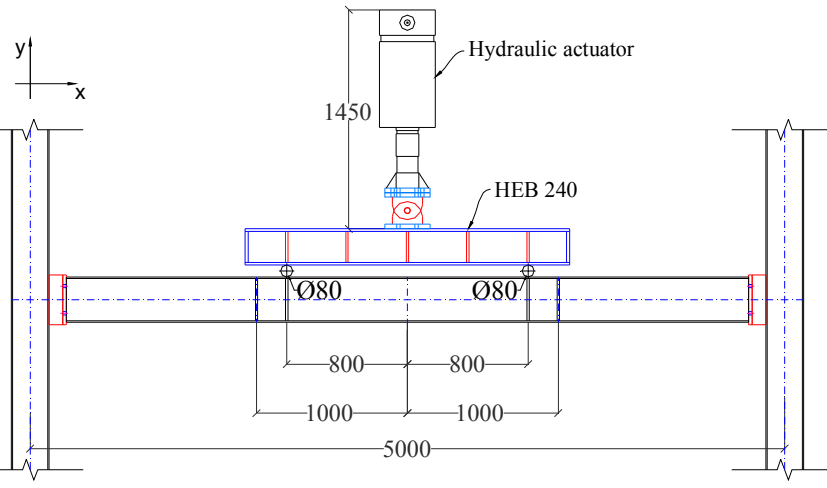

(b)

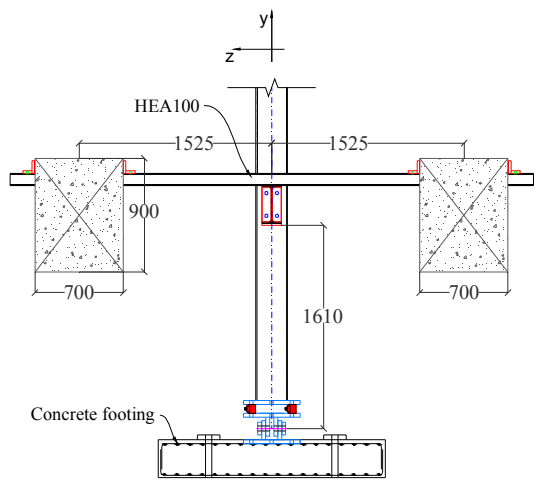

Figure 3. Mechanical Loading: (a) at Ambient Temperature; (b) under Heating-cooling Curves

Flexible Ceramic Pad (FCP) heaters applied the thermal loading of the heating-cooling tests. Reverse channel, endplates, bolts, and beam (web and bottom flange) were heated, as shown in Figure 4. In order to simulate the heat sink of a concrete slab, flexible ceramic pads were not attached to the top flange of the beam. The columns were not directly heated.
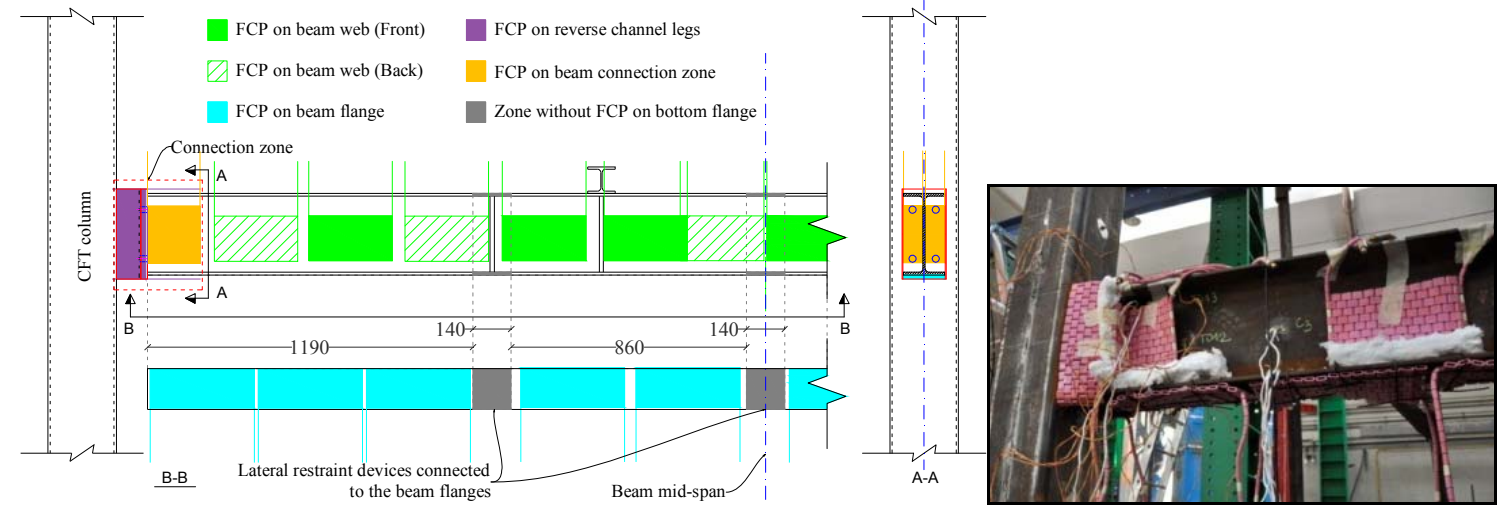

Figure 4. Heating Elements on the Beam and Connection

The steel temperatures were controlled in different zones: reverse channel, beam web, beam bottom flange, endplates and bolts. The heating rate and target temperature were previously defined a priori. To evaluate the effect of heating temperatures, two different heating profiles were used in the tests. A high heating rate was used for all tests: $800^{\circ} \mathrm{C} / \mathrm{h}$ (Tests 4,6 and 7) or $700^{\circ} \mathrm{C} / \mathrm{h}$ (Test 5) for the temperature control of the beam bottom flange and reverse channel, and $600^{\circ} \mathrm{C} / \mathrm{h}$ (Tests 4,6 and 7) or $500^{\circ} \mathrm{C} / \mathrm{h}$ (Test 5) for the temperature control of the beam web. The lower heating rates increases the duration of the heating phase in Test 5, allowing a more uniform distribution of temperature along the beam length. The heating rate for the endplates and bolts was around $400^{\circ} \mathrm{C} / \mathrm{h}$ for all tests. Figure 5 illustrates the heating profiles. When the temperature reached the target (Target temp. in Figure 5), i.e., $900^{\circ} \mathrm{C}$ (Tests 4,6 and 7) or $800^{\circ} \mathrm{C}$ (Test 5) in the beam bottom flange and $800^{\circ} \mathrm{C}$ (Tests 4,6 and 7 ) or $700^{\circ} \mathrm{C}$ (Test 5) in the beam web, the increase of the temperature was stopped and temperatures remained constant for about 15 minutes (End temp. in Figure 5). After that, the power units were turned off. The cooling phase developed without removing the thermal insulation. 


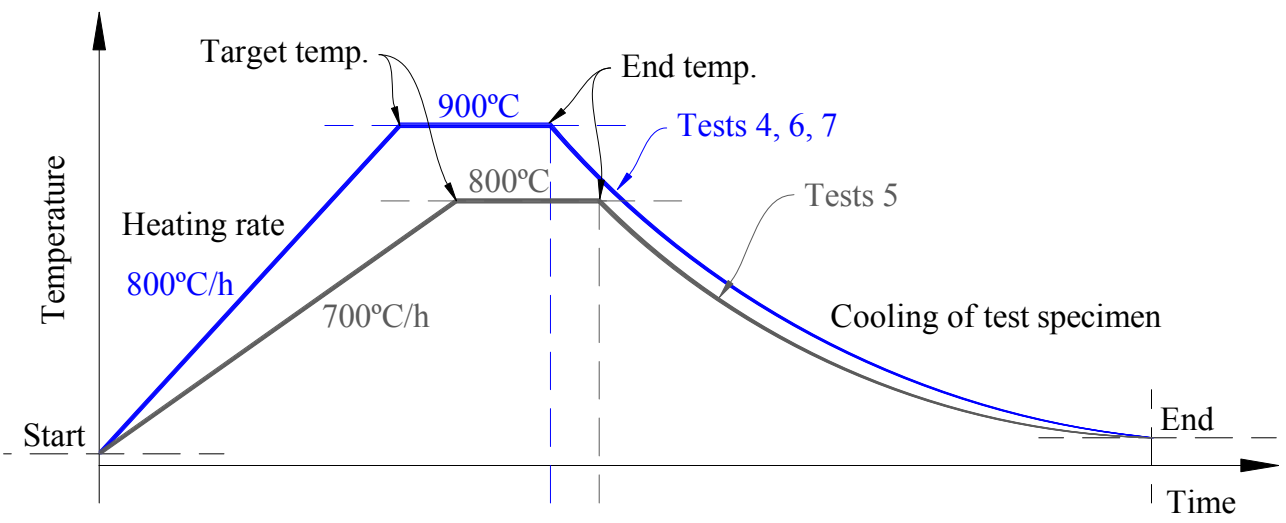

Figure 5. Control Temperature of the Heating Elements at the Beam Bottom Flange

\subsection{Instrumentation of Test Specimens}

The main requirements of the instrumentation were to measure the temperature, the distribution of internal/reaction forces and the deformed shape of the structural elements. Figure 6 illustrates the location of the load cells and displacement transducers in the experimental test set-up. A total of 72 thermocouples were employed to monitor the temperature evolution of the structure during the heating-cooling tests (Figure 7). The beam was divided into six sections of temperature control: sections 1,2 , and $3 \mathrm{a}$ were located at the left side of the beam, while sections $3 \mathrm{~b}$, 4, and 5 monitored the temperatures in the right side.

(a)

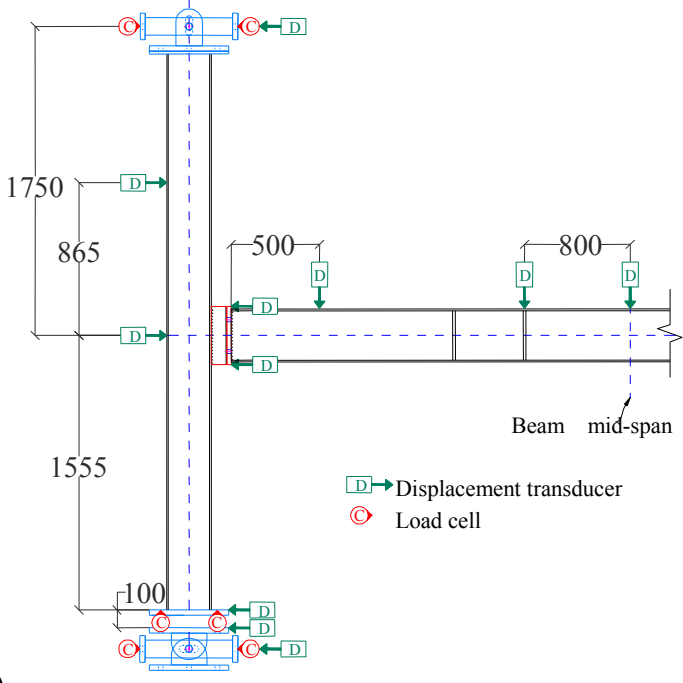

(b)

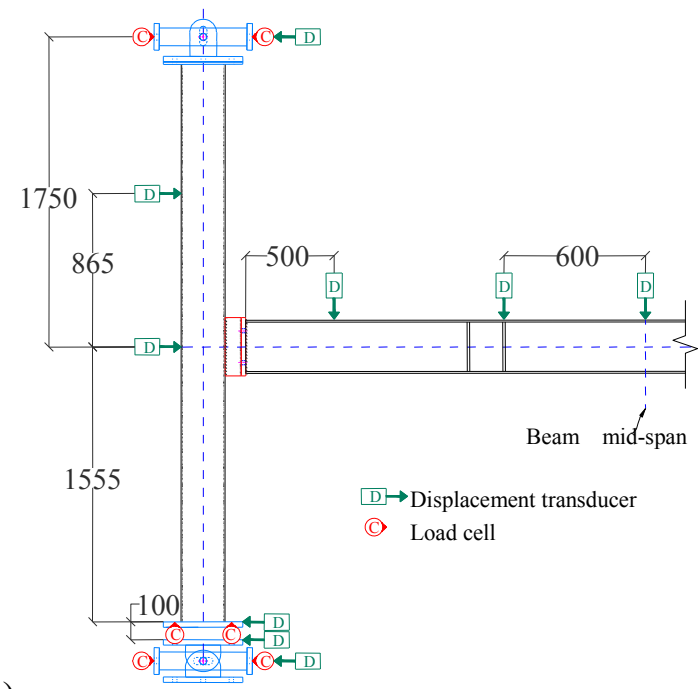

Figure 6. Location of the Load Cells and Displacement Transducers:

(a) Ambient Temperature Tests; (b) Heating-cooling Tests 


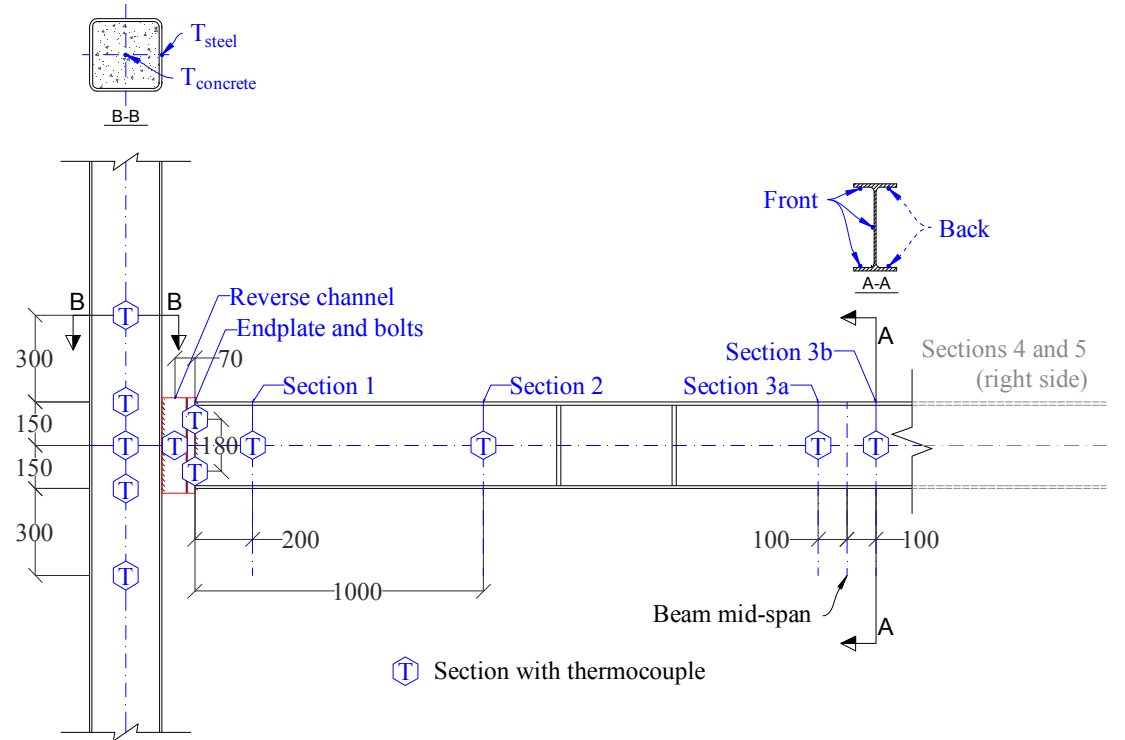

Figure 7. Location of the Thermocouples

\subsection{Control Tests and Material Properties}

Tensile tests of the main steel elements and compressive strength tests of the concrete infill of the columns were performed to obtain the mechanical properties to be considered for the validation of further numerical and analytical models. The steel test specimens were extracted from the beam web and flanges, the column walls, the endplate, and the reverse channel sections. A total of 24 test specimens were used for tensile tests at ambient temperature. The material of the reverse channel sections $(8,10$ and $12 \mathrm{~mm}$ thicknesses) was also tested at elevated temperatures, totalling 36 test specimens: 12 specimens were extracted from each reverse channel section and 3 tensile tests were performed for each constant elevated temperature: $200^{\circ} \mathrm{C}, 400^{\circ} \mathrm{C}, 600^{\circ} \mathrm{C}$ and $800^{\circ} \mathrm{C}$. The testing machine and some test specimens are shown in Figure 8. The tensile tests were performed according to ISO 6892-1 [15] and EN 10002-5 [16].

(a)

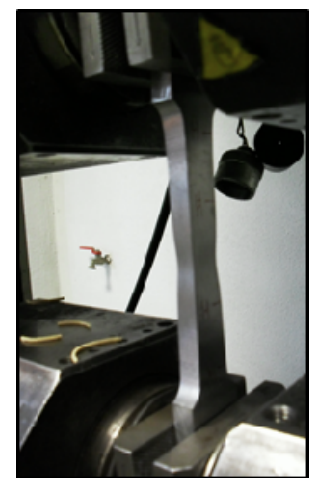

(b)

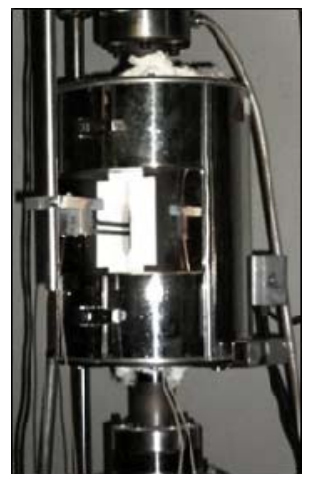

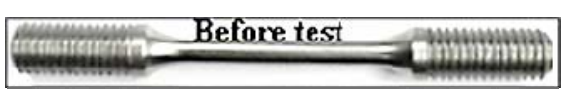

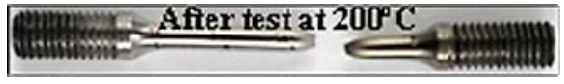

(c)

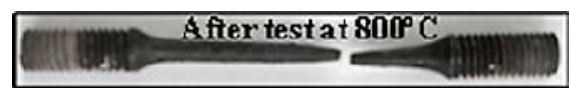

Figure 8. Tensile Tests of the Steel Materials: (a) Tensile Testing Machine; (b) Testing Furnace; (c) Test Specimens for Tensile Tests at Elevated Temperatures

The tensile nominal stress-engineering strain curves of steel at the ambient and elevated temperatures are illustrated in Figure 9. At ambient temperature (Figure 9(a)), the four typical regions of the stress-strain curve of a low carbon structural steel are very clear in the hot rolled specimens: linear elastic region, yield plateau, strain hardening region and strain softening or necking portion, after the maximum load has been reached; however, in the curves from the cold 
work specimens, the yielding plateau is not evidenced. Additionally, it is noted that for the same steel grade (S355), the yield strength and ultimate stress of the hollow sections (cold work specimen) were higher than the steel coupons cut from the beam (hot rolled specimen). The cold-formed steel sections also presented a decrease in ductility when compared with the steel of the beam and endplate; furthermore, the stress-strain curves obtained from hot-tension testing exhibit a much smaller spread between yield strength and ultimate, as shown in Figure 9(b). The increased strength caused by cold forming was drastically reduced at temperature above $600^{\circ} \mathrm{C}$ and the stress-strain curves exhibit a softening response after yielding. The stress-strain curves in Figure 9(b) show that the ductility of the cold form steel section was reduced when subjected to elevated temperature until $600^{\circ} \mathrm{C}$.

(a)

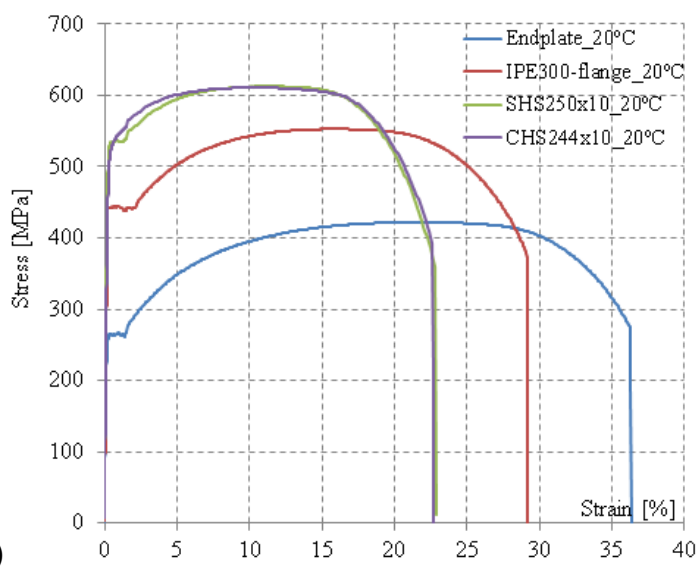

(b)

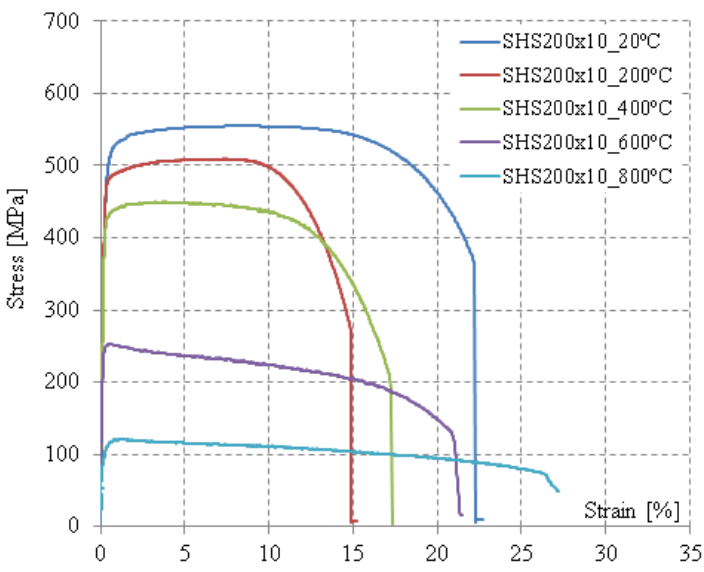

Figure 9. Strain-stress Curves of the Steel Materials: a) Ambient Temperature Tensile Tests;

b) Comparison of the Ambient and Elevated Temperature Tensile Tests of the Reverse Channel Sections

Table 3 summarizes the mechanical properties from tensile tests of the main steel elements.

Table 3. Mechanical properties of steels S275 and S355

\begin{tabular}{|c|c|c|c|c|c|}
\hline & \multirow{3}{*}{$\begin{array}{l}\text { EN 10025-5 } \\
\text { EN 1993-1-2 } \\
\text { Yield strength } \\
f_{y}(\mathrm{MPa})\end{array}$} & \multirow{2}{*}{\multicolumn{3}{|c|}{ Tests results }} \\
\hline & & & & & \\
\hline Steel & $\begin{array}{c}\text { Temp. } \\
\left({ }^{\circ} \mathrm{C}\right)\end{array}$ & & $\begin{array}{c}\text { Yield strength } \\
f_{y}(\mathrm{MPa})\end{array}$ & $\begin{array}{l}\text { Tensile } \\
\text { strength } f_{u} \\
(\mathrm{MPa})\end{array}$ & $\begin{array}{c}\text { Elongation } \\
\text { after fracture } \\
A(\%)\end{array}$ \\
\hline S275, End-plate & 20 & 275 & 236.7 & 424.7 & 40.1 \\
\hline S355, IPE 300 (flange) & 20 & 355 & 446.0 & 562.0 & 31.0 \\
\hline S355, SHS 250x10 & 20 & 355 & 554.7 & 621.3 & 27.0 \\
\hline S355, CHS $244.5 \times 10$ & 20 & 355 & 579.3 & 627.7 & 28.0 \\
\hline \multirow{5}{*}{ S355, SHS 200x10 } & 20 & 355 & 513.3 & 558.7 & 27.3 \\
\hline & 200 & 355 & 489.3 & 515.7 & 20.1 \\
\hline & 400 & 355 & 447.3 & 473.0 & 24.5 \\
\hline & 600 & 166.9 & 249.7 & 252.3 & 35.6 \\
\hline & 800 & 39.1 & 119.7 & 124.0 & 36.9 \\
\hline
\end{tabular}

All columns were filled with the same concrete mix. A total of 27 cubes were prepared and tested: three compression tests were performed after 7 days, 28 days, and also at the day of each sub-frame test. The tests at 28 days confirmed the concrete properties C30/37 according to EN 206-1 [17]. The strength average of the tests was $41.9 \mathrm{MPa}\left(f_{\mathrm{ck}, \text { cube }}\right.$ at 28 days $)$. 


\section{EXPERIMENTAL TEST RESULTS}

\subsection{Summary of the Test Results}

A summary of the ambient temperature and heating-cooling test results is presented in Table 4 . The deflection of the beam at the mid-span $\left(\Delta_{y, \max }\right)$ indicates the maximum deformation that was imposed at the mid-span of the beam. The axial force in the beam $\left(F_{\mathrm{x}}\right)$ resulted from the thermal expansion and contraction of the beam during the heating-cooling tests. In the tests at ambient temperature, in which there were not horizontal forces previously applied in the sub-frame, the horizontal reactions at the ends of the columns were very small.

Table 4. Summary of the Test Results

\begin{tabular}{llllll}
\hline Test & \multicolumn{1}{c}{ Temperature } & $\begin{array}{c}F_{\mathrm{y}, \max }{ }^{1} \\
(\mathrm{kN})\end{array}$ & $\begin{array}{c}\Delta_{\mathrm{y}, \max ^{2}}{ }^{2} \\
(\mathrm{~mm})\end{array}$ & $\begin{array}{c}F_{\mathrm{x}, \mathrm{comp}, \max ^{3}}{ }^{3} \\
(\mathrm{kN})\end{array}$ & $\begin{array}{c}F_{\mathrm{x}, \text { tens,max }}{ }^{4} \\
(\mathrm{kN})\end{array}$ \\
\hline 1 & Ambient & 356.3 & -127.1 & & \\
2 & Ambient & 379.5 & -138.6 & & \\
3 & Ambient & 530.4 & -295.1 & & \\
4 & Heating 1-cooling & 47.0 & -463.2 & -118.8 & 127.0 \\
5 & Heating 2-cooling & 47.0 & -115.0 & -137.9 & 14.7 \\
6 & Heating 1-cooling & 47.0 & -470.3 & -93.9 & 145.4 \\
7 & Heating 1-cooling & 47.0 & -358.6 & -128.0 & 155.7 \\
\hline
\end{tabular}

1 Total applied load; ${ }^{2}$ Maximum beam deflection at mid-span; ${ }^{3}$ Maximum beam axial force compresssion; ${ }^{4}$ Maximum beam axial force - tension

\subsection{Behaviour at Ambient Temperature}

\subsubsection{Failure modes}

Sub-frames from Test 1 and Test 2 failed due to the lateral-torsional buckling of the beams, as illustrated in Figure 10(a) and Figure 11(a), respectively. There was no failure of the joints although the reverse channels showed slight deformation that was mainly concentrated around the bolts holes in the tension zone. The bolts remained almost straight, and the endplates was almost undeformed after both tests (Figure 10(b) and Figure 11(b)). Besides that, the columns did not present any signs of damage.
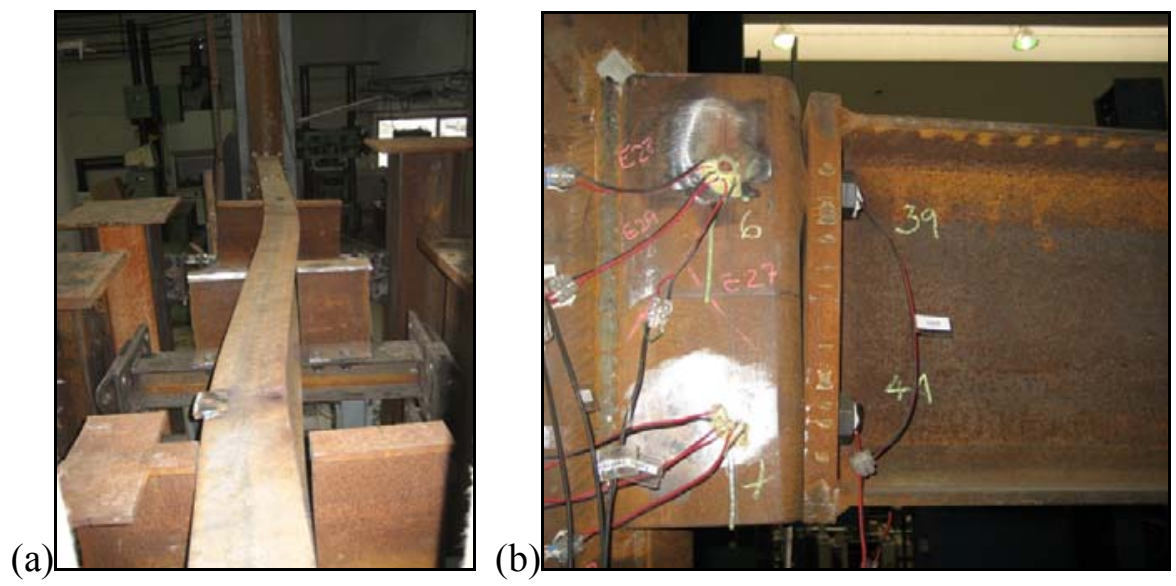

Figure 10. Deformed Shape in the Test 1: (a) Beam; (b) Connection 
(a)

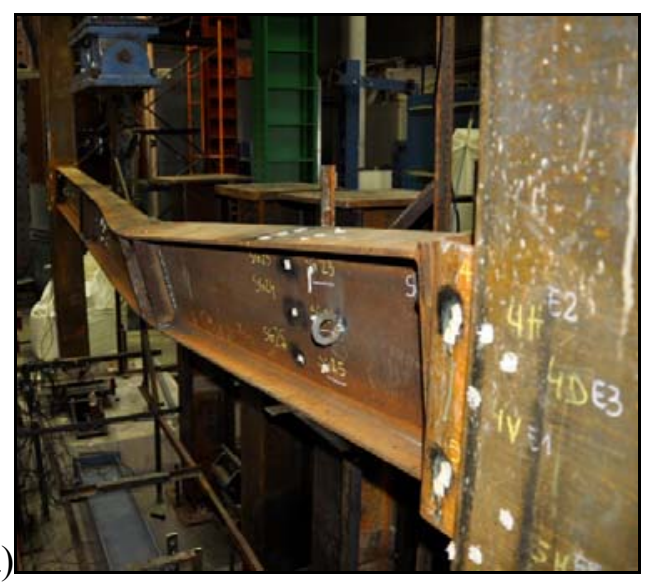

(b)

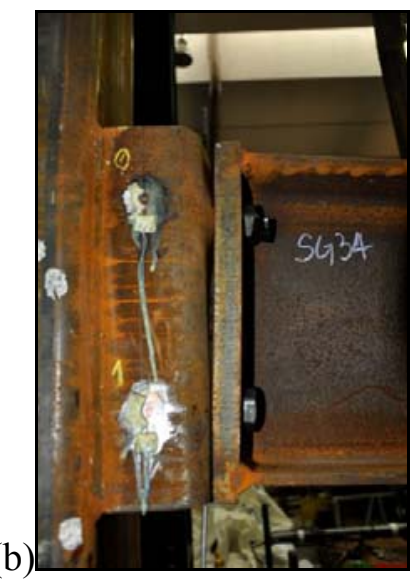

Figure 11. Deformed Shape in the Test 2: (a) Beam; (b) Connection

After Tests 1 and 2, the restraint system was reinforced to avoid the lateral-torsional buckling, and consequently increase the maximum applied load during Test 3 (Figure 12(a)). The connections experienced large deformation in both tension and compression zones, although the endplate did not show any deformation after the test, as observed in Figure 12(b).

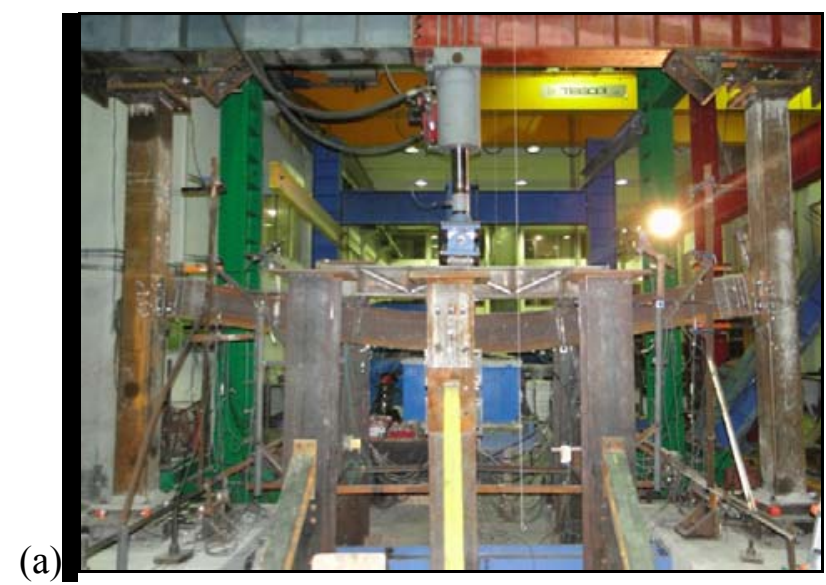

Figure 12. Deformed Shape in the Test 3: (a) Beam; (b) Connection

\subsubsection{Global behaviour}

The behaviour of the sub-frame in all ambient temperature tests presented four phases: (1) elastic deflection of the beam, increasing linearly with the mechanical loading, (2) reduction in the rate of increase in the applied load with a continuum increase in beam deflection, (3) decrease in the load carrying capacity of the beam due to failure, and (4) unloading.

In Test 1, the maximum load reached was $356.3 \mathrm{kN}$ and the beam mid-span deflection was 68.1 $\mathrm{mm}$ at the same time. After that, the beam lost its load carrying capacity gradually and the joints could not transmit the bending moment to the columns. Similarly, in Test 2, the maximum applied load was $379.5 \mathrm{kN}$ and the corresponding beam mid-span deflection was $94.3 \mathrm{~mm}$ (Figure 13). In test 3 , the maximum beam deflection was almost $300 \mathrm{~mm}$ at the mid-span, which corresponded to the maximum displacement of the piston of the actuator. Consequently, the test was finished with the maximum applied load of $530.4 \mathrm{kN}$ (Figure 12(a) and Figure 13). No failure was observed in the sub-frame and the third phase was not developed; the unloading procedure started after reaching 
the maximum piston stroke of the actuator.

(a)

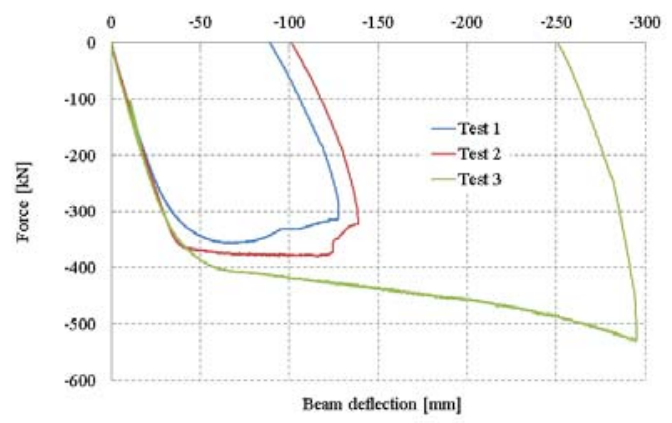

(b)

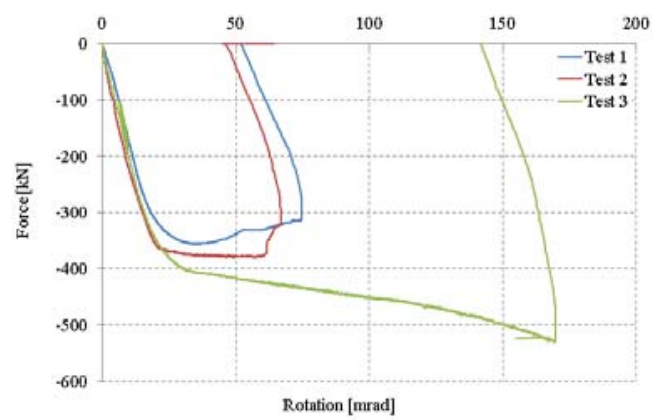

Figure 13. (a) Total Applied Load versus Beam Mid-span Deflection; (b). Total Applied Load versus Rotation of the Joint (left side)

The initial stiffness of the sub-frame was similar in the three tests at ambient temperature. The beam strength controlled the global behaviour of the structure. Due to the efficient lateral restraints, Test 3 presented the largest spread between plastic strength and maximum load applied on the beam, which is a typical behaviour of sub-assemblies with this type of joints, as observed in previous studies ([8], [11]).

The rotation of the joints could be calculated with the horizontal displacement obtained from the displacement transducer at each edge of the reverse channels, or using the vertical displacement of the beam near to the connection zones, as illustrated in Figure 6. Figure 13(b) presents the force-rotation relationship of the joints. The large deformation of the connections in Test 3 showed the high rotational capacity of the joints despite the thicker reverse channel's web.

\subsection{Behaviour at Elevated Temperature}

\subsubsection{Thermal response}

Figure 14 illustrates the evolution of the temperature in the tests. The beam bottom flange at mid-span reached a maximum temperature between $626^{\circ} \mathrm{C}$ and $763^{\circ} \mathrm{C}$, although the beam web reached higher temperatures at the same section for all tests.

The temperatures along the beam were not uniform neither constant, as a result of the heating method and the efficiency of the thermal insulation around the beam and the connections. The zones of the beam near to the connections (sections 1 and 5) had occasionally higher temperatures during the heating. As illustrated in Figure 14(b), the temperature was distributed more uniformly in the connection elements (i.e. reverse channel sections, beam endplates, and bolts). For each tested joint, the temperature curve in the endplate is similar to the one in the bolts; the reverse channel legs follow the heating of previous ones, but it reached lower maximum temperatures.

During Test 4 (Heating $1+$ Cooling), the heating process lasted about 83 minutes. After that, the heating machines were turned off. The beam reached the maximum temperature $\left(763.4^{\circ} \mathrm{C}\right)$ in the bottom flange after approximately 65 minutes. The cooling phase took about 10 hours until the temperature of the structure was about $50^{\circ} \mathrm{C}$. By safety conditions for workers, the thermal insulation of the beam and of the connections was kept until the total cooling of the structure in all tests. Unfortunately, this increased the duration of the cooling when compared to a natural fire.

In Test 5 (Heating $2+$ Cooling), the heating was slower than in Test 4 and it lasted about 
108 minutes. The maximum temperature in the beam bottom flange at the mid-span was $626.4^{\circ} \mathrm{C}$ after approximately 110 minutes of the start of the heating. The cooling phase lasted approximately 10 hours.

(a)

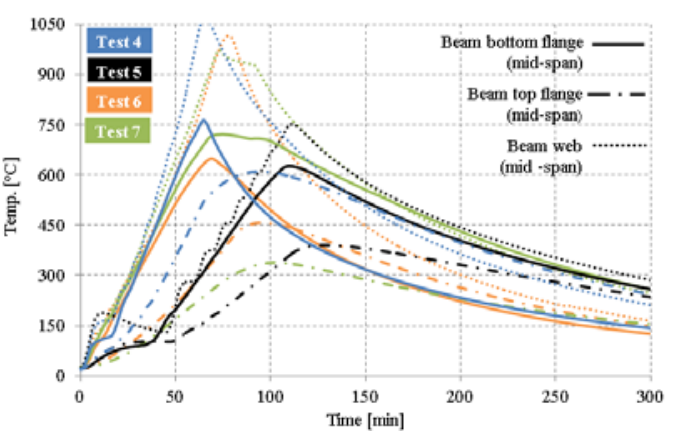

(b)

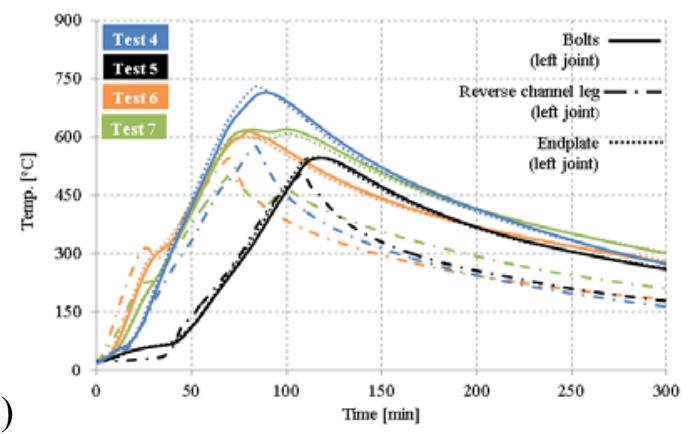

Figure 14. Temperature Evolution Curves: (a) Beam Mid-span (Section 3), (b) Left Joint

The heating profile of Test 6 was similar to Test 4 . The heating phase lasted about 83 minutes while the duration of the cooling phase was about 10 hours. The beam bottom flange reached a maximum temperature $\left(648.5^{\circ} \mathrm{C}\right)$ in the beam mid-span after approximately 69 minutes. After 61 minutes of the heating, the beam deflection started to increase quickly, when the temperature in the beam bottom flange at the mid-span was $607.1^{\circ} \mathrm{C}$. The heating process and temperatures distribution in Test 7 was similar to Test 6 .

\subsubsection{Mechanical response}

Figure 15 presents the evolution of the beam deflection at mid-span and the beam axial force during the entire duration of the fire. The beam deflection increased slowly durign the early stage of heating. The rate of increase of the deflection increased rapidly when the beam bottom flange reached temperatures between $587^{\circ} \mathrm{C}$ and $730^{\circ} \mathrm{C}$ at the mid-span. The lower temperatures in the beam mid-span and connection elements during Test 5 led to little deformation in the beam and connection, as well as the lowest deflection of the beam. The temperatures in the Test 7 were similar to the Test 6 , however, the ductility of the thinnest reverse channel in the Test 6 allowed the beam to undergo large deflection and plastic deformation without failure of the structure (Figure 15(a)). However, although the thickness of the reverse channel used in Test 6 was less than the used in Test 4, the maximum temperatures recorded in the connection of Test 4 were higher (the plate and bolts reached maximum values near $750^{\circ} \mathrm{C}$, as depicted in Figure $14(\mathrm{~b})$ ); these high temperatures caused higher ductility of the steel (according to the results presented in Section $\$ 2.4$, the strain at rupture decreases until $600^{\circ} \mathrm{C}$ but it increases again for higher temperatures), and thus the maximum deflection of the beam in Test 4 has reached maximum values near the ones observed in Test 6.

Concerning the axial force development represented in Figure 15(b), the axial restraint of the cold columns induced compression forces in the beam due to the thermal expansion during the heating phase. Since the beam reached its limit of axial resistance, it started to move downwards and the axial force, initially compressive, became in tensile forces. The beam experienced the inversion of forces during the heating in almost all tests. The maximum tensile forces reached at the end of the tests were higher than compressive force developed during the heating phase. Unlike the other tests, the speed deflection of the beam remained very low during the Test 5 . When the beam increased its deflection, this reduced the axial compressive force in the beam; nevertheless, it did not turn to tension. The axial force in the beam became almost zero at the end of the test. It should be recalled, 
that the difference between Test 5 and other tests is the heating-cooling profile only: the heating rate is lower $100^{\circ} \mathrm{C} / \mathrm{h}$ than the others tests and the maximum applied temperature was $100^{\circ} \mathrm{C}$ lower, however the mechanical response of the frame is completely different.

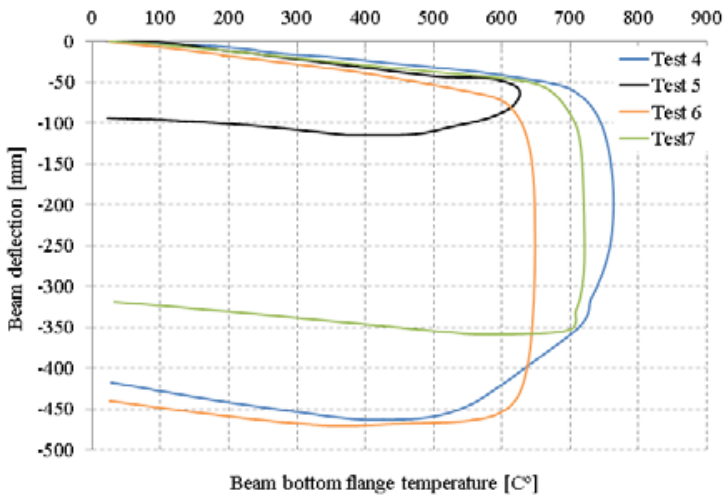

a)

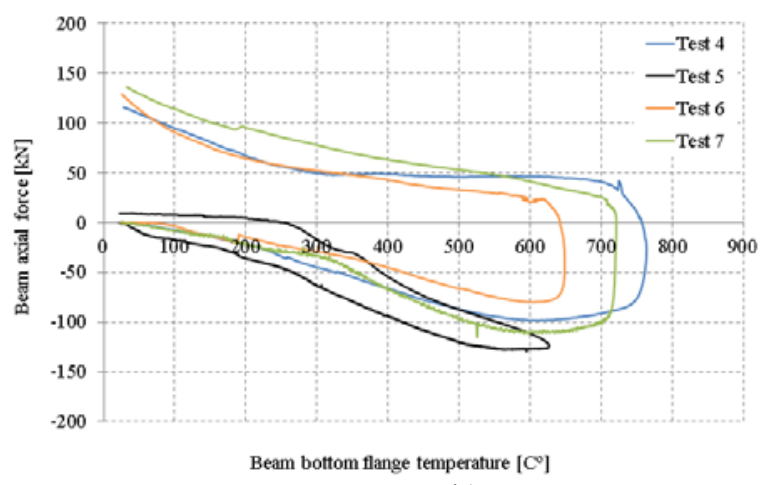

b)

Figure 15. a) Beam Vertical Deflection at the Mid-span; b) Beam Axial Force versus Temperature in the Beam Bottom Flange

\subsubsection{Failure modes}

Concerning the failure modes, the beam from Test 4 exhibited local buckling in the bottom flange and web shear buckling near to the connections (Figure 16). The endplate presented a large deformation; meanwhile, the reverse channel presented small deformations, which were specially concentrated around the bolts holes in the top row. This difference of deformation between end plate and reverse channel could be justified by the differences of maximum temperature reached in these components: the maximum end-plate temperature was above $700^{\circ} \mathrm{C}$ while in reverse channel it did not reach $600^{\circ} \mathrm{C}$. No failure was observed in the bolts. This behaviour was also responsible for the deflection of the beam, as explained in Section $\$ 3.3 .2$.
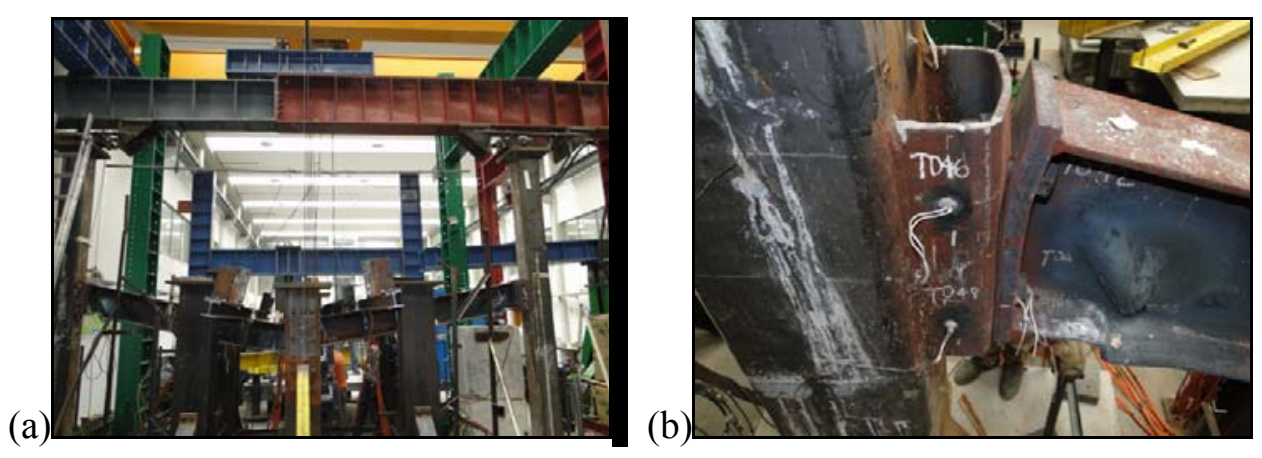

Figure 16. Deformed Shape in the Test 4: (a) Beam; (b) Connection

The beam from Test 5 presented the lowest deflection and the reverse channel and endplate did not have a noticeable deformation (Figure 17). The permanent deformations could only be observed in the beam bottom flange close to the connections. Again, these results show that even with small differences in the heating-cooling profile, the effect on the behaviour and failure modes is significantly different from the other tests. 
(a)
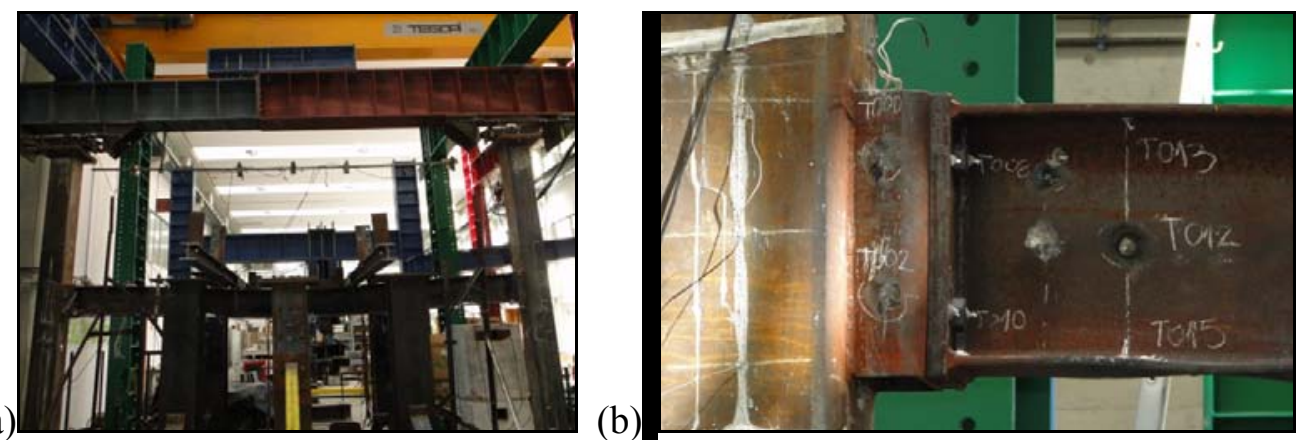

Figure 17. Deformed Shape in the Test 5: (a) Beam; (b) Connection

The highest deflection of the beam at the mid-span occurred in the Test 6 . Instead of Test 4, which had similar beam deflection, there is no local buckling in the beam near to the connections. The reverse channel presented large deformation at both the top and bottom zones, as illustrated in Figure 18(b). In this case, this behaviour is justified not by the differences on the temperature, but due to the reduced thickness of the reverse channel (only $8 \mathrm{~mm}$ ): a thinner reverse channel shows a lower rotational restraint and behaves similar to a pinned joint, inducing larger joint rotations and consequently, larger beam deflections; moreover, the axial restraint to the thermal expansion is also lower and local buckling didn't developed in the beam during the first stage of heating.

(a)

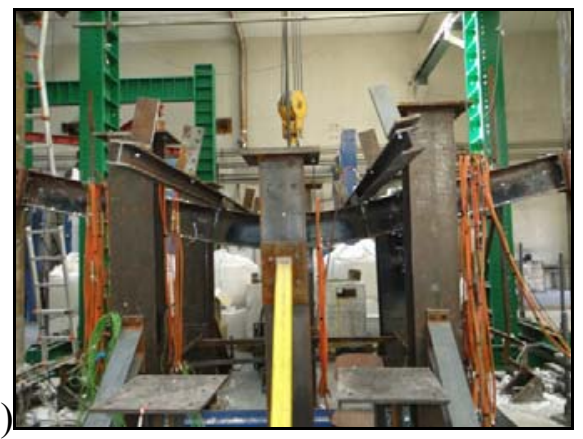

(b)

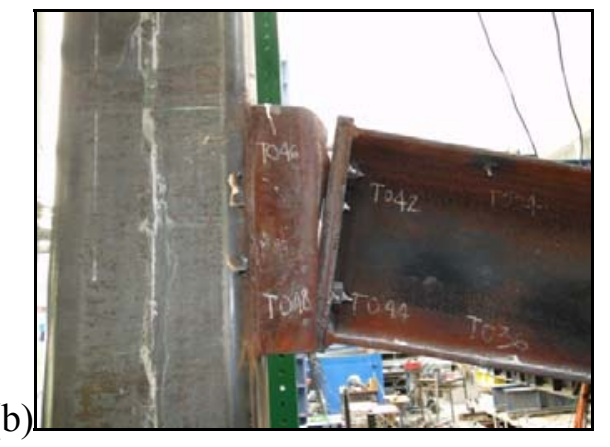

Figure 18. Deformed Shape in the Test 6: (a) Beam; (b) Connection

The beam experienced large deflection in the Test 7 although it was lower than Tests 4 and 6 (Figure 19). The endplates at both ends of the beam showed deformation at the top flange and local buckling of the beam web and bottom flange near to the connection was also noticed. Due to its high thickness $(12 \mathrm{~mm})$, the reverse channel showed almost no sign of damage after the test.
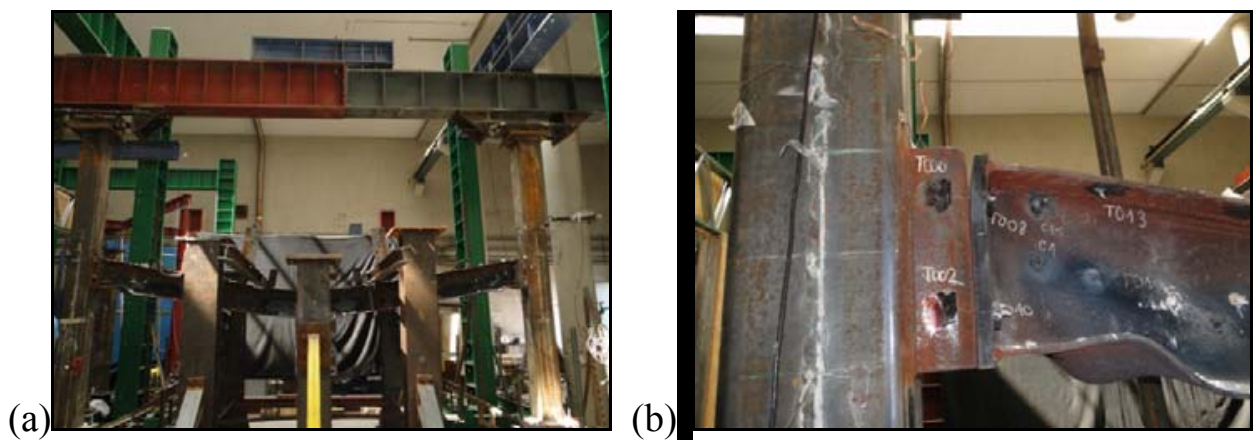

Figure 19. Deformed Shape in the Test 7: (a) Beam; (b) Connection 


\section{CONCLUSIONS}

This paper reports on the experimental results of the investigation on the coupled joint-structure behaviour of the composite sub-frame, using the reverse channel connections between an I-beam and the concrete filled tube (CFT) columns. Seven full-scale tests were performed: three tests at ambient temperature and four tests under two different heating curves, including cooling phase. The main objective of the tests was to provide information on the interaction between joint and the connected structural elements. The study aimed to understand the behaviour of the reverse channel connections during the development of bending, compression, local yielding and buckling and catenary action within the joint and its components.

In the ambient temperature tests, the first failure mode occurred due to the lateral instability of the beam. However, after efficiently restrained the beam, the results showed the large rotation capacity of the joint without global failure of the beam, despite the thicker reverse channel connection than those used in the tests with failure by lateral-torsional buckling.

During the heating-cooling tests, it was concluded that the development of the fire is also a key aspect on the global behaviour of the sub-frame; small differences in the heating - cooling profile could produce completely different results.

Moreover, as mentioned in the introduction of this paper, the demand for connection performance to prevent fracture is very high in fire design for structural robustness, and a way to prevent fracture is to enhance the connection's ductility rather than its strength. The tests showed that even with large deflection at the mid-span of the beam, no global collapse of the sub-frames was observed during the heating-cooling phases. The ductility of the thinnest reverse channel allowed the beam to undergo large deflection and plastic deformation without failure of the structure. The local failure was concentrated in the beam in those tests with thicker reverse channel; the thinnest reverse channel allowed the beam to deform without local buckling.

\section{ACKNOWLEDGEMENTS}

The research that produced these results was supported by funding from the European Community's Research Fund for Coal and Steel (RFCS) under grant agreement $n^{\circ}$ RFSR-CT-2009-00021 and also by the Portuguese Foundation for Science and Technology (FCT) under research projects PTDC/ECM/110807/2009

\section{REFERENCES}

[1] Schleich, J.B. and Cajot, L.G., "Natural Fire Safety Concept - Full Scale Tests, Implementation in the Eurocodes and Development of User-friendly Design Tools", Final Report, ECSC Research 7210-060, 1997-2000 - EUR 20580 EN, 2003, pp. 200.

[2] Lawson, R.M., "Behaviour of Steel-beam-to-column Connections in Fire", The Structural Engineer, 1990, Vol. 68, No. 14, pp. 263-271.

[3] Schleich, J.B. and Cajot, L.G., "Valorisation Project: Natural Fire Safety Concept", ECSC Research, 2001, 7215-PA/PB/PC-042/057, Belgium, pp. 80.

[4] Simões da Silva, L., Santiago, A., Vila Real, P. e and Moore, D., "Behaviour of Steel Joints and Fire Loading", International Journal of Steel and Composite Structures, 2005, Vol. 5, No. 6, pp. 485-513. 
[5] Santiago, A., Simões da Silva, L., Vaz, G., Vila Real, P. and Lopes, A.G., "Experimental Investigation of the Behaviour of a Steel Sub-frame under Natural Fire", Steel and Composite Structures, 2008, Vol. 8, No. 3, pp. 243-264.

[6] Neves, L.C., Simões da Silva, L. and Vellasco, P.C.G.S., "Experimental Behaviour of End Plate I-beam to Concrete-filled Rectangular Hollow Section Column Joints", International Journal of Applied Mechanics and Engineering, 2004, Vol. 9, No. 1, pp. 63-80.

[7] Silva, L.A.P., Neves, L.F.N. and Gomes, F.C.T., "Rotational Stiffness of Rectangular Hollow Sections Composite Joints", Journal of Structural Engineering, ASCE, 2003, Vol. 129, No. 4, pp. 487-494.

[8] Ding J. and Wang Y.C., "Experimental Study of Structural Fire Behaviour of Steel Beam to Concrete Filled Tubular Column Assemblies with Different Types of Joints", Engineering Structures, 2007, Vol. 12, No. 29, pp. 3485-3502.

[9] Simões da Silva, L., Santiago, A., Lopes, F., Veljkovic, M., Heistermann, T., Iqbal, N., Wald, F., Janá, T., Davison, B., Burgess, I., Huang, S-S., Dong, G., Wang, Y., Mandal, P., Hu, Y., Jafarian, M. and Koutlas, G., "COMPFIRE: Design of Composite Joints for Improved Fire Robustness", Final Report No. 4, 2013, Research Fund for Coal and Steel, Grant agreement n. ${ }^{\circ}$ RFSR-CT-2009-00021, European Commission, Brussels.

[10] Lopes F.C., Santiago A., Simões da Silva L., Heistermann T., Veljkovic M. and da Silva J.G.S., "Experimental Behaviour of the Reverse Channel Joint Component at Elevated and Ambient Temperatures”, International Journal of Steel Structures, 2013, Vol. 13, No. 3, pp. 459-472.

[11] Huang, S-S., Davison, B. and Burgess, I., "Experiments on Reverse-channel Connections at Elevated Temperature”, Engineering Structures, 2013, Vol. 49, pp. 973-982.

[12] Elsawaf, S., Wang, Y.C. and Mandal, P., "Numerical Modelling of Restrained Structural Subassemblies of Steel Beam and CFT Columns Connected Using Reverse Channels in Fire”, Engineering Structures, 2011, Vol. 33, pp. 1217-1231.

[13] EN 1993-1-8, Eurocode 3: Design of Steel Structures Part 1-8: Design of Joints, Brussels: European Committee for Standardization, 2005.

[14] Jaspart, J-P., Pietrapertosa, C., Weynand, K., Busse, E., and Klinkhammer, R., "Development of a Full Consistent Design Approach for Bolted and Welded Joints in Building Frames and Trusses between Steel Members Made of Hollow and/or Open Sections", Application of the component method. Draft final report - Volume 1: Practical design guide, Research Project 5BP, CIDECT, 2005.

[15] ISO. ISO 6892-1. Metallic Materials - Tensile Testing - Part 1: Method of Test at Room Temperature, International Organization for Standardization, 2009.

[16] CEN. EN 10002-5. Metallic Materials - Tensile Testing - Part 2: Method of Test at Elevated Temperature, European Committee for Standardization, 1991.

[17] CEN. EN 206-1. Concrete - Part 1: Specification, Performance, Production and Conformity, European Committee for Standardization, 2000. 